\title{
MOTIVASI MENIKAH LAGI: STUDI KASUS PASANGAN SUAMI ISTRI DARI SEORANG JANDA DAN DUDA YANG MENIKAH LAGI DI USIA LANJUT
}

\author{
Lutfi Anshori Syah, \\ Mulyadi, \\ Fakultas Psikologi \\ Universitas Islam Negeri Maulana Malik Ibrahim Malang \\ Jl. Gajayana, No 50 Malang \\ email: lutfisyahrustan@gmail.com
}

\begin{abstract}
Remarriage is starting a new marriage relationship between widow or widower with someone. Remarriage of the elderly is commonly happening nowadays. Remarriage is one of the ways done by the elderly to solve problem of loneliness and sexual intercourse loss due to the unavailability of the couples. The focus of this study are, how the motivation of widow and widower couples getting remarried in the elderly age, how the pattern of adaptation of the couples after marriage, and the implication of remarrying in the old age to the family. This research is designed as qualitative research by doing interview, observation, and documentation. The subject taken for this research is a couple of a widow and widower who remarry. The results of data analysis show that motivation possessed by a widow and a widower who remarry in their old age is that they want to elide loneliness and leisure, need of a couple, need composure in worship and need of happiness. The level of happiness within elderly couple who remarries is depend on adaptation process before and after marriage, adapting to each other and to the couple's children, and support from each of both families.
\end{abstract}

Keywords: motivation for marrying, elderly, family harmony

PSIKOISLAMIKA. Jurnal Psikologi Islam (JPI) copyright @ 2016 Pusat Penelitan dan Layanan Psikologi. Volume 13 Nomor 2 Tahun 2016

\section{PENDAHULUAN}

Probabilitas kematian alami pada orang berusia lanjut lebih besar jika dibandingkan dengan yang berusia lebih muda. Hal ini menjadikan masa lansia cenderung menjadi masa 'kesepian'. Meninggalnya teman, saudara, bahkan pasangan menjadikan relasi sosial para lansia menjadi terbatas. Bagi yang ditinggalkan oleh pasangannya, mereka akan berstatus janda atau duda. Janda atau duda akan menghadapi berbagai masalah pasca kematian pasangan. Salah satunya adalah masalah kesepian. Meskipun dalam pandangan masyarakat umum, usia lanjut dianggap sebagai usia degenerasi yang disertai dengan berbagai penyakit, tidak jatuh cinta, dan tidak memiliki gairah kepada lawan jenis, namun kenyamanan dan kebahagiaan tetap menjadi kebutuhan para lansia. Terlebih pada masa lansia, manusia mengalami penurunan kondisi fisik, kesendirian dan merasakan kesepian, sehingga perhatian secara fisik maupun dukungan psikis dibutuhkan. Atas dasar hal ini, maka para lansia yang berstatus janda dan duda memutuskan untuk menikah lagi walaupun dengan usianya yang sudah tua.

Saat ini menikah lagi pada usia lanjut lebih dimaklumi daripada masa lalu. Mellen (dalam 
Hurlock, 2002) menyimpulkan, bahwa menikah lagi dikalangan orang usia lanjut dewasa ini menjadi lebih sering dan bisa diterima masyarakat daripada pada masa dulu. Hal tersebut disebabkan sikap sosial masyarakat terhadap perkawinan pada usia lanjut sekarang menjadi lebih toleran, terutama ketika hilangnya pasangan hidup karena perceraian.

Studi kasus menikah lagi pada janda dan duda di usia lanjut ini terjadi pada pasangan suami istri yang sebelumnya merupakan janda dan duda di Desa X, Kecamatan X, Kabupaten Malang. Faktor pendukung kedua pihak memutuskan menikah kembali di usia lanjut antara lain: adanya dukungan dari keluarga dan anak-anak, pernikahan pertama yang bahagia, mengetahui sifat-sifat dan pola-pola perilaku apa yang diinginkan dari pasangan yang potensial, keinginan untuk menikah karena alasan mencintai dan membutuhkan teman.

\section{Motivasi Menikah Kembali (Remarried) di Usia Lanjut.}

Menikah kembali merupakan proses menjalin hubungan suami istri dengan pasangan baru yang sebelumnya sudah pernah menikah, sehingga keduanya membutuhkan adaptasi terhadap pasangannya dalam menjalani kehidupan (Hurlock, 1999). Faktor yang mendorong individu untuk menikah kembali (Remarried) di Usia Lanjut adalah : a) Faktor Biologi, b) Faktor Etika, Moralitas, dan Norma Sosial, c) Faktor Kebutuhan Ekonomi (keuangan), d) Faktor Status Sosial, e) Faktor Pemeliharaan dan Pendidikan Anak-anak, , f) Faktor Pemeliharaan dan Pendidikan Anak-anak. Kepuasan dalam pernikahan kembali, lebih besar dirasakan pada wanita dibandingkan laki-laki, kemungkinannya karena wanita lebih menekankan pada pencapaian kepuasan pernikahan dibandingkan laki-laki (Santrock, 2002).

Ketika para lansia memutuskan untuk menikah kembali, mereka akan menghadapi beberapa masalah khas, yaitu masalah penyesuaian dengan dirinya, pasangan baru, dan keluarga baru, rumah baru dalam lingkungan masyarakat yang sama, dan terkadang dengan lingkungan yang baru (Hurlock, 2002). Oleh karena itu, dalam proses menikah kembali dibutuhkan penyesuaian. Menurut Wahyuningsih (2002) terdapat tiga pola penyesuaian yang harus dilakukan oleh pasangan yang telah melakukan pernikahan, yaitu a)Compromise (kompromi), b) Accommodate, c) Hostility (Permusuhan). Pola-pola penyesuaian tersebut dipengaruhi oleh beberapa faktor yakni tingkat penyesuaian suami atau istri sebelum menikah, sikap terhadap pernikahan, motivasi melakukan pernikahan, proses memilih pasangan, dan karakteristik demografi yang dimiliki suami atau istri.

\section{Usia Lanjut}

Ketika seorang individu memasuki masa lanjut usia, terdapat 4 stereotype yang terjadi. Pertama, usia lanjut merupakan usia yang tidak menyenangkan. Kedua, usia lanjut cenderung menimbulkan sikap negatif yang memperkuat pendapat klise yang ada tentang orang usia lanjut tidak menyenangkan. Ketiga, usia lanjut merupakan orang yang memiliki fisik dan mental yang loyo, usang, sering pikun, jalannya membungkuk, dan sulit hidup bersama dengan siapapun. Keempat, orang usia lanjut mempunyai status kelompok minoritas, menua membutuhkan perubahan peran, penyesuaian yang buruk, dan keinginan menjadi muda kembali (Partini, 2010).

Para ahli memiliki pandangan berbeda mengenai masa lanjut usia. Cumming dan Henry mengemukakan sebuah teori tentang hubungan antara umur manusia dengan kegiatannya, yakni teori pengunduran diri dan teori aktivitas, yaitu teori pengunduran diri (disengagement). Teori ini berpendapat bahwa semakin tinggi usia manusia akan diikuti oleh secara berangsur-angsur semakin mundurnya interaksi sosial, fisik dan emosi dengan kehidupan dunia. Teori ini bertolak belakang dengan teori aktivitas (activity theory) Neugarten dkk, yang menyatakan bahwa agar usia lanjut berhasil maka individu pada usia lanjut harus tetap beraktivitas seaktif mungkin. Semakin tua seseorang akan semakin memelihara hubungan sosial, baik fisik maupun emosionalnya. Sedangkan Atchely menekankan bahwa manusia tetap perlu memelihara satu hubungan antara masa lalu dan masa kini sepanjang hidupnya (Partini, 2010). Pengunduran diri merupakan keadaan alami yang terjadi pada individu lansia seiring degenarasi yang terjadi pada kemampuan fisik maupun psikis. Individu akan semakin pasif karena berkurangnya kapabilitas sebagaimana empat stereotype masa lansia. Namun pandangan teori aktivitas menganjurkan perlawanan terhadap keadaan alami tersebut agar individu lansia tetap dapat menjalani masa tuanya dengan positif. Keaktifan pada lansia juga berefek positif secara psikis paska kematian pasangan. Umumnya wanita lebih mempersiapkan diri secara psikis dalam menghadapi kematian pasangan. Seorang janda berusia lanjut secara psikis tampak telah siap ketika ditinggalkan pasangannya. Mereka berusaha menyesuaikan dirinya untuk menghilangkan 
kekosongan dengan aktif melakukan kegiatan sosial (Heyman \& Gianturco, 1973). Demikian pula dengan pendapat Atchely, ia berpendapat masa lansia tidak seharusnya dijalani secara pasif melainkan dimanfaatkan untuk memelihara satu hubungan antara masa lalu dan masa kini.

\section{Kebahagiaan Keluarga}

Kebahagiaan merupakan sejumlah perasaan yang ada dalam jiwa seseorang yang dapat dirasakan dan diaktualisasikan berupa perasaan senang, tentram, dan memiliki kedamaian atau ketenangan bathin (Rusydi, 2007). Sedangkan keluarga merupakan suatu kelompok yang mempunyai nenek moyang yang sama, memiliki kekerabatan yang disatukan oleh darah atau perkawinan, berupa pasangan pernikahan dengan adanya anak atau tanpa anak, yang hidup dalam suatu masyarakat.

Kebahagiaan dan kepuasan hidup merupakan kondisi positif yang dituju oleh semua orang. Tercapainya kebahagiaan maupun kepuasan dalam hidup memerlukan pemenuhan kebutuhan, baik fisik maupun psikis. Pemenuhan kebutuhan fisik berupa sandang, pangan, papan, serta kesehatan sebagai upaya untuk mempertahankan hidup dan reproduksi, adalah kebutuhan yang dapat diamati pemenuhannya. Namun kebutuhan psikis lebih rumit pemenuhannya. Misalnya kebutuhan akan kasih sayang, cinta dan perhatian. Kebutuhan untuk berkomunikasi dengan orang lain, kebutuhan untuk disayangi, dicintai, diperhatikan dan kebutuhan untuk berhubungan dengan Tuhan adalah contoh kebutuhan usia lanjut yang tidak boleh diabaikan (Partini, 2010).

Kebahagiaan dalam keluarga tidak akan dirasakan oleh janda dan duda lansia yang tidak terpenuhi kebutuhan fisik maupun psikis. Anggota keluarga lain seperti anak-anak dapat menjamin terpenuhinya kebutuhan fisik, namun tidak dengan kebutuhan psikis. Sebagaimana telah disebutkan sebelumnya, kebutuhan psikis memiliki tingkat kerumitan tersendiri dalam pemenuhannya. Salah satu problem khas dari kebutuhan psikis lansia adalah kebutuhan untuk berkomunikasi, disayangi, dicintai, diperhatikan. Kebutuhan-kebutuhan tersebut sering sulit dipenuhi oleh anak-anak karena terdapat kesenjangan pendapat antara anak dan orangtua lansia. Gaya hidup keluarga moderen yang cenderung sibuk juga menjadi penyebab terhambatnya pemenuhan kebutuhan-kebutuhan tersebut.

\section{METODE}

Pendekatan penelitian ini adalah penelitian kualitatif, yaitu penelitian yang menggunakan manusia sebagai instrumennya, menghasilkan data deskriptif berupa kata-kata tertulis atau lisan dari orang-orang dan perilaku yang dapat diamati (Moleong, 2004). Sesuai dengan permasalahan yang menjadi fokus dalam penelitian ini yaitu motivasi menikah kembali pada pasangan suami isteri dari seorang janda dan duda yang menikah lagi di usia lanjut, (Studi Kasus di Desa X, Kecamatan X, Kabupaten Malang), maka peneliti menggunakan pendekatan kualitatif dengan memakai bentuk studi kasus (case study) dengan paradigma fenomenologis yang mencoba memahami arti dan peristiwa dan kaitannya terhadap orang-orang biasa dalam situasisituasi tertentu.

Teknik pengumpulan data adalah hal yang penting dalam penelitian, karena tujuan dari penelitian adalah mendapatkan serta mengumpulkan data. Dalam penelitian ini, peneliti menggunakan metode wawancara, observasi, dan dokumentasi yang umum dipakai dalam penelitian kualitatif. Narasumber dalam penelitian ini adalah seorang janda dan seorang duda lanjut usia yang melakukan pernikahan kembali di Desa X, Kecamatan X, Kabupaten Malang. Pada penelitian kualitatif tidak menggunakan populasi karena penelitian kualitatif berangkat dari kasus tertentu, situasi sosial tertentu, dan hasil penelitiannya tidak berlaku pada populasi, tetapi di transferkan ke tempat lain pada situasi sosial pada kasus yang diteliti (Sugiyono, 2005).

\section{HASIL}

Banyak orang pada usia lanjut yang menyadari bahwa suatu saat pasangan hidup mereka akan meninggal, oleh karena itu mereka telah mempersiapkan diri untuk menghadapinya, atau siap menyesuaikan diri dengan situasi kesepian yang akan terjadi (Heyman \& Gianturco, 1973).

Salah satu cara yang dilakukan oleh orang yang sudah berusia lanjut dalam mengatasi masalah kesepian dan hilangnya aktivitas seksual, karena hilangnya pasangan hidup adalah dengan menikah lagi. Dewi (2005) menyebutkan motivasi yang dimiliki lansia menikah lagi ialah untuk mengurangi rasa kesepiannya setelah ditinggalkan oleh pasangannya, memenuhi kebutuhan psikologis, masalah sosial, masalah tempat tinggal, masalah ekonomi, dan untuk memenuhi kebutuhan fisiologi. Untuk menunjang pernikahan kembali di usia lanjut adalah persetujuan dari anak dan saudara ketika akan menikah lagi, 
kondisi kesehatan yang baik dan memungkinkan untuk menikah lagi, serta mengetahui sifat-sifat dan perilaku dari pasangan yang sesuai dengan keinginanannya.

Keputusan menikah lagi yang dilakukan oleh pasangan suami isteri dari seorang janda dan duda di Desa X, Kecamatan X, Kabupaten Malang juga dilatarbelakangi alasan yang serupa. Kedua subjek menikah lagi karena adanya beberapa faktor yang menjadi motivasi untuk menikah kembali. Faktorfaktor tersebut adalah adanya dukungan dari keluarga terutama anak-anak subjek, pernikahan pertama yang bahagia, mengetahui sifat-sifat dan pola perilaku yang diinginkan pasangan, saling mencintai dan membutuhkan teman, untuk melepaskan rasa kesepian dan kosong dalam menjalani hidup di usia senja, untuk meningkatkan kualitas hidup di usia lanjut, dan keinginan adanya seseorang yang bisa memimpin dan membimbing bagi dirinya dan keluarga.

Dukungan keluarga terutama anak-anak dari pasangan sebelumnya merupakan salah satu faktor yang menjadikan pernikahan akan bahagia. Subjek mengatakan bahwa orang tua yang akan menikah lagi terlebih dahulu harus meminta izin atau pesetujuan dulu dari anak-anak dan keluarga. Adanya dukungan dari anak-anak subjek akan membantu mendekatkan ikatan emosi kedua subjek dengan keluarga terutama anak-anak. Anak-anak menjadi mampu menyambut baik dengan kehadiran orang baru dalam lingkungan keluarga. Hal ini terbukti setelah kedua subjek menikah, subjek tetap berkunjung ke rumah anakanaknya walaupun hanya sekedar keinginan untuk menengok kondisi cucu-cucunya.

Pernikahan kedua bagi subjek merupakan pernikahan yang harus lebih memberikan manfaat, ketenangan bathin, bisa saling mengasihi, dengan syarat dari keduanya harus benar-benar siap untuk menikah. Hal ini sesuai dengan yang diungkapkan Hurlock (1999), usia lanjut yang menikah lagi cenderung untuk mengenang sesuatu yang indah pada masa lalu (pernikahan pertama), dan seberapa besar orang lanjut usia dalam mengingat kembali masa lalunya tergantung pada kondisi hidup seseorang di usia lanjutnya. Makin senang kehidupan di usia lanjut, maka makin besar kenangan-kenangan indah untuk mengulangnya.

Menurut Erikson (dalam Desmita, 2012) mengatakan, keintiman pada perkawinan di usia lanjut sebagai suatu kemampuan memperhatikan orang lain dan membagi pengalaman dengan pasangan. Pembentukan hubungan intim dan persaudaraan lebih didambakan bagi pasangan usia lanjut yang menikah lagi, sekalipun pasangan usia lanjut harus berkorban untuk mendapatkannya. Sedangkan dalam pemenuhan kebutuhan seksual, kedua subjek mengatakan pemenuhan kebutuhan seksual bukan lagi sebagai tujuan utama dari pernikahannya di usia lanjut, hal ini karena adanya pertimbangan pada kondisi kesehatan dan kekuatan dari pasangan. Subjek tidak menganggap hal tersebut sebagai suatu hal yang penting dalam pernikahan kali ini. Hurlock (1999) memaparkan, bagi pria, semakin bertambahnya usia, minat seksualnya lebih besar dibandingkan dengan aktivitas seksualnya, sedangkan bagi wanita justru sebaliknya, karena wanita dalam hal aktivitas dan seksualnya tidak berubah. Ketidakseimbangan antara kekuatan fisik dan minat seksual membuat individu lansia akan mencari bentuk-bentuk aktivitas lain bersama pasangan yang dapat memenuhi minat seksualnya ketimbang memaksakan aktivitas seksual. Pemaksaan dalam aktivitas seksual dapat menimbulkan efek psikologis yang parah dibanding manfaatnya. Penyaluran perilaku seksual yang tidak menyenangkan akan mengakibatkan perasaan bersalah, stres, emosional dan perasaan tidak enak terhadap pasangan.

Kedua subjek tidak pernah memaksa pasangan untuk malakukan aktivitas seksual. Kepuasan aktifitas seksual menurut kedua subjek bukan hanya sekedar menyangkut masalah sering atau tidaknya dalam melakukan hubungan seksual, tetapi yang penting adalah apakah aktivitas seksual tersebut sudah memenuhi kebutuhan kedua belah pihak pasangan. Setelah menikah kedua subjek dalam mengekspresikan perilaku seksualnya dengan bersama-sama mengisi waktu luang, bercanda, saling memandang, dan saling memberikan perhatian.

Perasaan-perasaan dan kebutuhan seksual subjek terpenuhi dengan saling memandang, berkumpul bersama, menonton televisi bersama, bercerita, bercanda dan berbagi pengalaman. Kedua pasangan lebih memfokuskan diri pada bentuk hubungan sebagai persaudaraan yang memiliki ikatan batin yang dekat. Hal tersebut ditunjukkan dengan memperlihatkan kasih sayang kepada pasangan, seperti meluangkan waktu, merawat dan membantu kebutuhan sehari-hari pasangan, saling memberikan kepercayaan, dan membantu dalam keseharian jauh lebih dianggap oleh subjek sebagai kebutuhan yang paling penting dalam pernikahannya di usia lanjut (wawancara, 2016).

Stenberg, (1993), mengatakan cinta terdiri dari tiga unsur utama. Pertama, cinta berdasarkan 
gairah, artinya cinta lebih didasarkan pada daya tarik fisik dan seksual pada pasangan. Kedua, cinta lebih didasarkan pada keintiman, artinya cinta lebih didasarkan pada perasaan emosional tentang kehangatan, kedekatan, dan berbagi dalam hubungan. Ketiga, adalah cinta yang memiliki pengertian sebagai komitmen, artinya cinta yang lebih didasarkan pada penilaian kognitif atas hubungan dan niat untuk mempertahankan hubungan, bahkan ketika menghadapi masalah sekalipun (Santrock, 1995).

Pada pernikahan kembali yang dilakukan pasangan lansia, cinta di antara keduanya didominasi oleh dasar keintiman dan komitmen. Yudrik (2011) menyebutkan, kondisi yang menunjang (motivasi) penyesuaian pernikahan kembali di masa usia lanjut adalah pernikahan pertama yang bahagia, mengetahui sifat-sifat dan perilaku dari apa yang dicari pasangan potensial, keinginan untuk menikah lebih pada keinginannya untuk mencinta dan membutuhkan teman, daripada alasan untuk melanjutkan perilaku seksual. Di sisi lain, urgensi komitmen dalam pernikahan disadari kedua subjek sebagai faktor pernikahan dapat bertahan dan harmonis. Subjek pertama menuturkan, bahwa ketika sebuah pernikahan didasari rasa cinta dan komitmen, maka pasangan akan lebih bahagia. Rasa cinta dan komitmen dibutuhkan karena ketika setelah menikah, istri atau suami merupakan orang yang paling dipercaya secara penuh, tidak ada lagi hal masalah rumah tangga yang ditutupi. Subjek pertama memaknai seorang istri bukan hanya sebagai figur kepercayaan dan pendamping hidup, melainkan seorang istri merupakan orang yang bisa mengerti segala perasaan suami, mampu mendorong dan menjadi pelipur dalam suka dan duka, serta medidik keluarga.

Kedua subjek mengatakan setiap manusia yang hidup pasti butuh untuk menikah walaupun sudah berusia lanjut, karena banyak sekali manfaat yang didapatkan. Hal ini didukung oleh Bograd dan Splika (dalam Santrock, 1999), menikah kembali pada masa lansia akan lebih percaya, menerima, dan tidak perlu lagi untuk berbagi perasaan pribadi yang dalam. Selain itu, pria lansia cenderung lebih puas terhadap pernikahan kembali pada masa lansia dibandingkan dengan pria setengah baya.

\section{Penyesuaian Setelah Menikah Lagi}

Penyesuaian diri setelah pernikahan merupakan tantangan khas yang ditemukan pada setiap jenjang usia pernikahan, termasuk pada pasangan usia lanjut yang menikah lagi setelah ditinggal oleh pasangan dari pernikahan sebelumnya. Beberapa pola penyesuaian perlu dilakukan oleh kedua subjek sebelum menikah dan setelah menikah, agar pasangan bisa saling mengetahui tentang kondisi dan perilaku yang dimiliki, tidak ada perasaan malu, saling menghargai, terjalin komunikasi yang baik. Pada pernikahan kembali yang dilakukan pasangan lansia, penyesuaian diri yang perlu dilakukan sebelum dan setelah menikah, berkaitan dengan relasi terhadap dengan pasangan dan keluarga, terutama anak-anak dari keduanya.

Menurut Wahyuningsih (2002) keberhasilan pola penyesuaian pada orang lanjut usia yang menikah lagi dipengaruhi oleh beberapa faktor, yaitu:

a. Tingkat penyesuaian suami atau isteri sebelum menikah.

b. Sikap terhadap pernikahan

c. Motivasi melakukan pernikahan

d. Proses dalam memilih pasangan

e. Karakteristik demografi yang dimiliki pasangan.

f. Penyesuaian Keuangan, kemudian

Alasan kedua sejak pertama kali menerima lamaran dari subjek 1 , subjek 2 memiliki keinginan agar mendapatkan seorang suami yang benar-benar memiliki niat dan komitmen serta bisa dijadikan pemimpin dan pembimbing di hari tua.

Penyesuaian dalam hal keuangan kedua subjek dapat dilalui dengan baik. Kedua subjek sejak awal pernikahan kembali tidak mengalami kesulitan dalam masalah keuangan. Subjek 2 dalam tidak pernah mempermasalahkan atau menuntut kepada subjek 1. Subjek 2 merasa sudah tercukupi dari hasil kerja subjek 1 dan tunjangan dari anak-anak subjek 2 . Selain itu subjek 2 memiliki perasaan kasihan dan simpati terhadap pasangan (wawancara, 2016). Kedua subjek memiliki pandangan bahwa pernikahan pada orang yang sudah lanjut usia bukan merupakan suatu kesalahan karena keduanya memiliki tujuan dan niat yang baik. Sehingga ketika akan menikah lagi, tidak ada hal-hal yang dianggap menjadi faktor penghambat (seperti masalah keuangan dan usia) karena yang terpenting dari pernikahannya keduanya memiliki tujuan yang sama dan tidak merepotkan orang lain terutama anak-anak dan keluarga.

Hubungan kedua subjek dengan keluarga pasangan sudah terjalin sejak pasangan memutuskan untuk menikah. Adanya dukungan keluarga dari subjek dengan keluarga pasangan terutama anak-anak memotivasi subjek sering mengunjungi keluarga pasangan. Anak-anak dari pasangan menerima dan menyambutnya dengan senang. Karena kedekatan 
subjek dengan keluarga pasangan baik, anak-anak dapat menerima kedua subjek sebagaimana orang tua kandung.

Kebahagiaan pernikahan sebagai seorang dewasa lanjut sangat dipengaruhi oleh kemampuan masing-masing pasangan dalam menghadapi dan memecahkan konflik-konflik yang terjadi dengan pasangan ataupun dengan anak-anak pasangan sebelumnya, termasuk menghadapi proses penuaan, sakit, dan kematian (Condi, 1989). Saat terjadi masalah atau konflik setelah pernikahan dengan pasangan maupun dengan anak-anak keluarga pasangan, kedua subjek menyelesaikannya dengan cara bermusyawarah, menahan emosi dan menginteropeksi diri. Kedua subjek melakukannya dengan ketiga cara ini sebagai metode yang paling tepat untuk memecahkan masalah keluarga baik dengan pasangan ataupun dengan anak-anak dari keluarga pasangan. Alasan kedua menerapkan metode ini, karena banyak dari beberapa kasus pernikahan dan keluarga tidak bisa terpecahkan jika kedua belah pihak hanya mengedepankan emosi, kesabaran dan interospeksi diri.

\section{DISKUSI}

Kebahagiaan yang dirasakan kedua subjek usia lanjut setelah menikah lagi adalah hadirnya sosok yang membantu menghadapi perasaan kosong dan kesepian dalam menjalani kehidupan di usia lanjut, serta meningkatnya aktivitas keseharian yang bias dilakukan bersama pasangan seperti memberikan perhatian, melaksanakan ibadah bersama pasangan

\section{DAFTAR PUSTAKA}

Condi, S.J. (1989). Older Married Couples. Dalam

\section{S.J. Bahr \& E.T. Peterson}

Desmita. (2006). Psikologi Perkembangan. Bandung. PT. Remaja Rosda Karya

Dewi. (2007). Cermin Dunia Kedokteran. 34 (3): 134-9. Faktor Resiko yang Berperan terhadap terjadinya Depresi pada Pasien Geriatri yang dirawat di RS. Dr. Cipto Mangunkusumo. (versi elektronik). Diakses pada tanggal 19 desember 2015 dari http://www.kalbe.co.id/cdk

Heyman, D. K., and D.T. Gianturco. Long-term Adaptation by The Elderly to Bereavement. Journal of Gerontology, 1978. 28, 359-362.

Moleong, L. (2001). Metodologi Penelitian Kualitatif. Bandung: Remaja Rosda Karya dengan tenang, saling mendampingi, membantu, dan merawat di usia lanjut. Menurut

Kebahagiaan yang didapatkan kedua subjek setelah menikah lagi berupa ketenangan bathin, tidak lagi merepotkan keluarga terutama anak-anak, lebih fokus mengurus rumah tangga masing-masing, merasa bahagia karena adanya dukungan dari anakanak, dan lebih tenang dalam menjalankan ibadah bersama pasangan. Penelitian selanjutnya dapat mengeksplorasi pengambilan keputusan dalam memilih pasangan menikah di usia lanjut, karena dinamika pemilihan pasangan dapat mempengaruhi keputusan untuk melakukan pernikahan kembali.

\section{KESIMPULAN}

Motivasi utama yang dimiliki oleh pasangan untuk menikah lagi di usia lanjut adalah, keinginan untuk mendapatkan seorang pendamping hidup yang bisa mengurus dan mengatur keperluan sehari-hari, menghilangkan kesepian di usia lanjut, mendapatkan ketenangan batin, meningkatkan ibadah seharihari. Pasangan suami istri yang menikah lagi di usia lanjut harus mampu menyesuaikan dengan pasangan, anak-anak, keluarga dari kedua belah pihak, serta perlu adanya sikap saling menghormati dan menerima kondisi yang dimiliki oleh pasangan. Penyelesaian masalah sebaiknya dilakukan dengan cara bermusyawarah, menjaga emosi, dan intropeksi diri. Implikasi dari menikah lagi di usia lanjut terhadap kebahagiaan keluarga akan dirasakan oleh pasangan, jika pernikahan tersebut anak-anak dari kedua belah pihak mendukungnya.

Jahja Yudrika. (2002). Psikologi Perkembangan. Jakarta: Kencana

Hurlock. (2002). Psikologi Perkembangan. Jakarta: Erlangga

Partini, S. (2010). Psikologi Usia Lanjut. Yogyakarta: Gajah Mada University Press

Rusydi, A.C. (200). Analisis Faktor yang Mempengaruhi Kebahagiaan. Bandung: Rosda Karya

Santrock, John W. (2002). Perkembangan Masa Hidup. Jakarta: Erlangga

Sugiyono. (2003). Memahami Penelitian Kualitatif. Bandung: Alfabeta

Sligment. Jane Moore, A Hellen. (1996). Sosiologi Wanita. Jakarta: Rineka Cipta

Wahyuningsih. (2007). Psikologi Perkembangan Usia Lanjut. Jakarta: Erlangga 